NBER WORKING PAPER SERIES

\title{
PRODUCTIVITY GROWTH AND R\&D \\ EXPENDITURE IN TAIWAN'S \\ MANUFACTURING FIRMS
}

\author{
Jiann-Chyuan Wang \\ Kuen-Hung Tsai
}

Working Paper 9724

http://www.nber.org/papers/w9724

\section{NATIONAL BUREAU OF ECONOMIC RESEARCH \\ 1050 Massachusetts Avenue \\ Cambridge, MA 02138}

May 2003

We would like to thank Professor Tsutomu Miyagawa, Professor Jungho Yoo and two anonymous referees for their insightful suggestions and comments. The views expressed herein are those of the authors and not necessarily those of the National Bureau of Economic Research.

C2003 by Jiann-Chyuan Wang and Kuen-Hung Tsai. All rights reserved. Short sections of text not to exceed two paragraphs, may be quoted without explicit permission provided that full credit including (C) notice, is given to the source. 
Productivity Growth and R\&D Expenditure in Taiwan's Manufacturing Firms Jiann-Chyuan Wang and Kuen-Hung Tsai

NBER Working Paper No. 9724

May 2003

JEL No. L6

\begin{abstract}
This study sets out to estimate the impact of R\&D on productivity within the private sector, with further analysis of the different impacts of R\&D in high-tech and conventional firms. The study also aims to estimate the rates of return on R\&D investment and total factor productivity at firm level. Based on a sample of 136 large manufacturing firms listed on the Taiwan Stock Exchange over the period 1994-2000, our findings suggest that Taiwan's R\&D investment had a significant impact on firm productivity growth, with output elasticity standing at around 0.18 . When the sample is divided into high-tech and conventional firms, the R\&D output elasticity in high-tech firms is significantly greater than that of conventional firms. In addition, the average rate of return in high-tech firms is much larger than that estimated in other industries. Our empirical findings further show that although there was a dramatic decline in TFP in 1998 for all selected industries, this nevertheless started to climb again in 1999.

Jiann-Chyuan Wang

Chung-Hua Institution for Economic Research

75 Chang-Hsing St., Taipei, Taiwan, 106

jcw@mail.cier.edu.tw

Kuen-Hung Tsai

Department of Shipping and Transportation Management

National Taiwan Ocean University

2 Pei-Ning Road, Keelung, Taiwan, 202

tmas@mail.ntou.edu.tw
\end{abstract}




\section{INTRODUCTION}

Ever since the 1960s, research and development (R\&D) investment has been regarded as an important factor in the improvement of productivity levels. The rationale is that knowledge, which can be created and accumulated through the R\&D efforts of a firm or industry, will subsequently become available to product innovations or to the production process (Mansfield, $1965 ; 1969)$, and as a result, nationwide economic development is promoted; indeed, the advanced countries have invested significant expenditure on $R \& D$ activities based upon this rationale. ${ }^{1}$

Two notable issues have been explored, the first of which is the extent to which R\&D influences productivity, whilst the second is concerned with the rates of return provided by R\&D. Numerous studies have attempted to estimate the marginal product of R\&D capital, or the rates of return on R\&D investment (see for example Griliches, 1980; 1994; Scherer, 1983; 1993; Griliches and Lichtenberg, 1984; Goto and Suzuki, 1989). Based upon several different levels of data aggregation, or different types of estimation model, these studies demonstrate that the output elasticity of R\&D lies between 0.06 and 0.14 , whilst the rates of return on privately financed $R \& D$ investment are between 20 per cent and 50 per cent. However, these studies have continually failed to produce consistent results, with some even failing to determine the contribution of R\&D to productivity growth (Link, 1983; Griliches and Lichtenberg, 1984).

A substantial amount of $R \& D$ expenditure is invested annually in Taiwan's manufacturing sector. According to data reported by the National Science Council (NSC) (2001), the average share of $R \& D$ expenditure within the manufacturing sector accounts for over 95 per cent of domestic R\&D expenditure; however, the resultant growth in TFP,

\footnotetext{
${ }^{1}$ For example, the average annual rates of R\&D expenditure in the US and Japan, relative to GDP, are around 2.64 per cent and 3.04 per cent, respectively (NSC, 2001).
} 
the impact of $R \& D$ on productivity growth, and the rate of return on $R \& D$ expenditure have seldom been seriously examined at firm level. This study sets out, therefore, to estimate firm productivity growth based upon panel data for a sample of 136 firms for the period 1994-2000. The aims of the study are to determine to what degree R\&D influences productivity, to further estimate the rates of return on R\&D investment within manufacturing firms, and to analyze the differences in productivity growth and the rates of return on $R \& D$ investment between industries. Finally, we will test the famous Schumpeterian hypothesis, that the returns on $R \& D$ are an increasing function of firm size.

Following on from this introduction, the remainder of this paper is organized as follows. In the next section we undertake a review of previous studies in this area, followed by an introduction to the methodology adopted in this study, including both the model and the data resources employed in the estimations. Some basic statistics and the results of our estimations and tests are presented and interpreted in the penultimate section. We conclude with some remarks on our findings in the final section, where we also offer some suggestions for further research.

\section{LITERATURE REVIEW}

In any general examination of previous studies, there are two main considerations; the first is the level of data aggregation, and the second is the type of estimation model used. At firm level, Griliches and Mairesse (1984; 1990) and Cuneo and Mairesse (1984) used time series data to estimate the contribution of $R \& D$ based on the production function model. They found that the approximate output elasticity of R\&D capital lies between 0.06 and 0.10. In a cross-sectional study, Griliches (1995) further demonstrated that the output elasticity of R\&D stock was around 0.09-0.14. Adopting the model of R\&D intensity, Clark and Griliches (1984), Griliches (1986) and Lichtenberg and Siegel (1989) showed that in US 
manufacturing firms, the rates of return on R\&D were between 10 per cent and 39 per cent. Goto \& Suzuki (1989) further concluded that the rates of return on R\&D investment in Japanese manufacturing industries tended to be around 40 per cent, and Wakelin (2001) demonstrated that the rates of return on $R \& D$ capital were around 27 per cent in UK manufacturing firms. However, in an earlier study, Link (1983) found that the R\&D coefficient in US manufacturing industries in the 1970s failed to achieve statistical significance.

At industry level, most researchers adopt an R\&D intensity model. Terleckyj (1974), Griliches and Lichtenberg (1984), Scherer (1993) and Griliches (1994) each found that the rates of return on privately financed $R \& D$ investment were between 20 per cent and 50 per cent in US manufacturing industries, whilst Goto and Suzuki (1989) showed that the estimated $R \& D$ rates of return in Japanese manufacturing industries were around 26 per cent. Furthermore, van Meijl (1997), Vuori (1997) and Hanel (2000) found that the rates of return on R\&D investment within manufacturing industries in France, Finland and Canada were around 19 per cent, 14 per cent and 34 per cent, respectively. It should be noted, however, that Scherer (1983) concluded that the impact of R\&D on productivity was insignificant.

There are two points worth noting from any examination of the previous studies. First of all, most of the empirical findings demonstrate that $R \& D$ investment does have a significant effect on productivity growth or value added; but we should also keep in mind that such a general summary of prior empirical studies may be overoptimistic because of the 'file drawer' problem, i.e., the likelihood of studies supporting the null hypothesis (no significant results) being rejected and therefore buried away in file drawers (Rosenthal, 1979; Begg and Berlin, 1988). 
Secondly, estimations with the R\&D intensity model often neglect the obsolescence of R\&D. Most of the previous studies have substituted R\&D expenditure for increments in $R \& D$ capital in order to avoid the difficult task of measuring R\&D capital; however, such a substitution not only neglects the reduction in the effective appropriation of knowledge but also overestimates the net rates of return on R\&D (see for example Wakelin, 2001; Hanel, 2000; Lichtenberg and Siegel, 1991; Griliches and Lichtenberg, 1984).

\section{METHODOLOGY}

\section{The Model}

In common with most analyses of the contribution to productivity growth from R\&D (see for example, Griliches, 1986; Goto and Suzuki, 1989; Lichtenberg and Siegel, 1991; Hanel, 2000; Wakelin, 2001), the model adopted for this study is the extended Cobb-Douglas production function model: ${ }^{2}$

$$
Q_{i t}=\mathrm{A} e^{\lambda t} L_{i t}^{\alpha} K_{i t}^{1-\alpha} R_{i t}^{\gamma} e^{\varepsilon_{i t}}
$$

where $\mathrm{Q}, \mathrm{L}, \mathrm{K}$ and $\mathrm{R}$ respectively represent value added (or sales), labor, physical capital and R\&D capital. R\&D capital is a measurement of the stock of knowledge possessed by a firm at a given point in time; $\lambda$ is the rate of disembodied technical change; A is a constant; and constant returns to scale have been assumed with respect to the conventional factors ( $\mathrm{L}$ and $\mathrm{K})$. The parameters, $\alpha$ and $\gamma$, are the output elasticity of labor and R\&D capital.

By taking logarithms of the variables, equation (1) can be expressed in log form: ${ }^{3}$

\footnotetext{
2 One could of course consider more complicated functional forms, such as the Trans-log or CES functions, but we use the C-D function based on most empirical studies and on some exploratory computations.

${ }^{3}$ By taking logs differentiated with respect to time, and imposing the equality of rates of return on $R \& D$
} 


$$
(q-k)_{i t}=a+\lambda t+\alpha(\ell-k)_{i t}+\gamma_{i t}+v_{i t}
$$

where the variables in lower case $(q, l, k$, and $r)$ are the respective logarithms of value added, labor, physical and R\&D capital, and $v_{i t}$ is the error term in the equation. Equation (2) is the model employed to estimate the impact of $R \& D$ on productivity growth. Based upon the estimate of $\gamma$ in equation (2) and the definition of R\&D output elasticity, the rates of return on R\&D investment can be easily estimated across firms and over periods. Furthermore, to test the Schumpeterian hypothesis, another equation as follows is considered:

$$
(q-k)_{i t}=a+\lambda t+a(l-k)_{i t}+\gamma_{i t}+\gamma_{s} s+e_{i t}
$$

where the variable $s$ is the logarithm of the product of R\&D capital by assets, $\gamma_{s}$ is the coefficient linking the relationship between the firm size and the impact of $R \& D$ on productivity, and $e_{i t}$ is the error term in the equation (3).

Two points are worth noting relating to the disturbance terms, $v_{i t}$ and $e_{i t .}$ Firstly, in addition to the inputs listed in the model, some unobservable factors, such as managerial capabilities, also have considerable impacts on the creation of a firm's value added (Wernerfelt, 1984; Barney, 1991; Deteraf, 1993). These factors will vary across firms, thus, the variances of $v_{i t}$ and $e_{i t}$ are heteroskedastic. In other words, the variance derived from some unobservable factors is viewed as an error component of $v_{i t}$ and $e_{i t}$.

Secondly, within our data set, each firm is observed at several points during each

across firms, or over periods, we can rewrite equation (1) as a linear function of R\&D intensity: $(d Q / Q-d K / K)_{\mathrm{it}}=\lambda+\alpha(d L / L-d K / K)_{\mathrm{it}}+\rho(d R / Q)_{\mathrm{it}}+e_{\mathrm{it}}$, where $\rho=d Q / d R$, representing the increment in value added generated by a unit increase in R\&D resource $\theta$ years earlier. With the newly-expressed model, we would obviously estimate $\rho$ directly; however, we have not pursued such an alternative model here since this model presupposes that the rate of obsolescence of R\&D capital is zero and assumes that the rates of return on R\&D investment are equal across firms and over periods. 
year, and some factors omitted from equation (2) and (3) may be correlated across periods. After accounting for this possibility, it seems reasonable to model the data as having serial correlation. Since the empirical literature is overwhelmingly dominated by the auto-regression with first order serial correlation (AR (1)) model (Greene, 1993), the disturbance process with an AR (1) form is assumed in our model. To summarize, these two problems will be considered in the estimations since they could result in biased or inefficient estimates.

\section{The Data and Variables}

The examination of related issues is based on a longitudinal data set which includes a sample of 156 large firms stratified from the Taiwan Stock Exchange (TSE). As a result of a number of missing observations on R\&D expenditure, and questionable data on other variables, we have limited the sample to 136 firms. These samples are fully balanced over the seven-year period, 1994-2000.

The sample covers most R\&D performing manufacturing industries, including food (11 firms), textiles (31 firms), chemicals (30 firms), metals (9 firms), machinery (12 firms) and electronic equipment (43 firms). ${ }^{4}$ Since the number of firms within each of these industries is too small to work with separately, we classify the sample into two groups, high-tech firms within the electronic equipment industry (32 per cent), and other industrial firms (68 per cent). ${ }^{5}$ Through this method of classification, in addition to alleviating the problem of heterogeneity, the difference in $R \& D$ effect on productivity growth between the high-tech sector and other manufacturing firms can also be explored.

Table 1 provides some general information on the samples and variables, in the

\footnotetext{
4 Electronic equipment includes computers and peripherals, integrated circuits (IC), telecommunications and other electronics.

${ }^{5}$ Here we divide the sample into two because R\&D expenditure is the indicator most widely used in identifying high-tech organizations or industries (Baruch, 1997).
} 
form of descriptive statistics, with columns three to six respectively representing labor growth rates, physical capital, value added and $R \& D$ to sales ratio (R\&D intensity) across each sector for the period 1994-2000. The figures in the last column of Table 1 represent R\&D intensity for each industry in 2000 .

Table 1 Growth rate of major variables and $R \& D$ to sales ratio

\begin{tabular}{lcccccc}
\hline \multicolumn{1}{c}{ Industry } & $\mathrm{N}^{\mathrm{a}}$ & Labor & Capital & Value Added & GRS $^{\mathrm{b}}$ & RS $^{\mathrm{c}}$ \\
\hline Food & 11 & 0.03 & 6.31 & 5.35 & -0.007 & $0.85(0.29)$ \\
Chemicals & 30 & 0.19 & 7.68 & 2.73 & 0.035 & $1.61(2.00)$ \\
Textiles & 31 & -0.52 & 8.06 & 5.20 & -0.004 & $0.49(0.51)$ \\
Machinery & 12 & -1.25 & 6.58 & 9.70 & 0.003 & $1.59(0.98)$ \\
Metals & 9 & 0.41 & 1.93 & 1.02 & -0.027 & $0.66(0.29)$ \\
Electronic equipment & 43 & 5.72 & 18.85 & 22.53 & 0.052 & $3.79(2.35)$ \\
Total & 136 & 1.65 & 10.71 & 10.67 & 0.021 & $1.68(2.44)$ \\
\hline
\end{tabular}

Notes:

${ }^{\text {a }} \mathrm{N}$ is the number of firms;

b GRS is the growth rates of R\&D to sales ratio;

${ }^{c} \mathrm{RS}$ is the R\&D to sales ratio in year 2000, (figures in parentheses are standard deviations).

Based on the figures provided in Table 1, there are a number of interesting observations to be made. First of all, the growth rates of labor and physical capital in the electronic equipment industry are, to a great extent, higher than in other industries. Secondly, the average growth rate of $R \& D$ to sales ratio is much more rapid in 'high-tech' firms than in other firms. Moreover, the R\&D intensity in high-tech firms is much higher than in other firms; for example, in 2000, the average ratio of R\&D to sales in electronic equipment was around two to five times that of other firms. Thirdly, there is much more rapid growth in both R\&D intensity and value added in high-tech firms. In summary, the statistics provided in Table 1 suggest substantially noticeable development of the electronic equipment industry in Taiwan.

Whilst noting the descriptive statistics provided in Table 1, it is worth keeping in mind that although our sample firms are so-called large manufacturing firms, firm size differs significantly. During the observed periods, for all industries, all of the variation 
coefficients of the variables are large; for example, in 2000, the respective variation coefficients of labor and fixed assets in the electronic equipment industry were around 137 per cent and 60 per cent. These figures show that to a large degree, the dispersion of firm size is high.

In addition to output (value added), labor and physical capital, another major variable in the estimation model is R\&D capital, which has been viewed as a measurement of the current state of technical knowledge, determined, in part, by current and past R\&D expenditure (Griliches, 1979). In other words, an increase in R\&D capital in period $t$ reflects not only the $\mathrm{R} \& \mathrm{D}$ expenditure of period $t$ but also previous $\mathrm{R} \& \mathrm{D}$ expenditure which bears fruit during the period. There is some sort of distributed lag structure that connects past $R \& D$ expenditure to a current increase in technical knowledge, and ideally, one would like to estimate the lag structure from the data. Unfortunately, it is difficult to obtain the information required to determine the lag structure, thus, we simply use the average lag.

With the simplification of R\&D impact lag structure (average lag), the measurement of firm R\&D capital is often expressed as: $R_{t}=E_{t-\theta}+(1-\delta) R_{t-1}$ (following Griliches, 1980; Goto and Suzuki, 1989; and Odagiri and Kinukawa, 1997), where $E$ is a deflated measure of R\&D, $\theta$ is the average lag and $\delta$ is the rate of obsolescence of R\&D capital. ${ }^{6}$ The equation leads to R\&D expenditure in period $t$ - $\theta$ becoming R\&D capital in period $t$. Assuming that the growth rate of $R \& D$ capital is equal to the growth rate of $E$, the $R \& D$ capital of the original period is obtained as: $R_{0}=E_{1-\theta} /(g+\delta)$, where $g$ is the growth rate of E.

\footnotetext{
${ }^{6}$ Other forms of lag structure, such as geometrically declining weights, could be assumed; however, various constructed lag measures and different initial conditions make little difference to the results (Griliches and Mairesse, 1984).
} 
Following on from the approach of Goto and Suzuki (1989), we use the average lag $\theta$, based on simplifying evidence. Patents are a good indicator of benefit creation (Bound, et. al., 1984; Pakes and Griliches, 1984; Griliches, 1998), and according to Lin and Lee (1996) and Tsai (1997), R\&D investment has a significant impact on patents two years later. Moreover, a simulation study indicated that the lag length of the effect of $R \& D$ expenditure on productivity growth lies between one to three years (Xu, et al., 1998). These findings suggest that the average lag in Taiwan is around two years. Pakes and Schankerman (1984) also demonstrated that the R\&D lag for the chemicals, machinery and electronics industries is around two years; therefore, we set the average lag length as $2(\theta=2)$ to measure R\&D capital. ${ }^{7}$

The depreciation rate $(\delta)$ reflects the replacement of old knowledge with new knowledge, or the reduction in the effective appropriation of knowledge. As suggested by Goto and Suzuki (1989), we examine the length of time taken by firms' patents to generate revenue in order to estimate the rate of obsolescence of $R \& D$ capital. We use the inverse of the length of time to measure the rate of obsolescence of R\&D capital with the firms investigated being the sample used in our analysis. Amongst these firms, the average rates of obsolescence were around 14.5 per cent in general machinery, 6.2 per cent in food, 12.4 per cent in chemicals, 7.2 per cent in textiles, 6.5 per cent in metals and 20.4 per cent in electronic equipment. ${ }^{8}$

\footnotetext{
${ }^{7}$ Lagged R\&D expenditure is used in many studies but there is no general agreement on the correct lag length. Hall and Mairesse (1995) pointed to the stability of firm R\&D expenditure in the US and Germany, and the insensitivity of the results to the choice of lag.

${ }^{8}$ Odagiri and Kinukawa (1997) estimated the rate of obsolescence of R\&D capital in four Japanese industries, electrical machinery, transportation machinery, general machinery and chemicals. The respective rates of obsolescence were 13.9 per cent, 11.3 per cent, 7.2 per cent, and 9.2 per cent. Goto and Suzuki (1989) also demonstrated that the respective rates of obsolescence of R\&D capital in seven Japanese industries were: 24.6 per cent (precision machinery), 14.5 per cent (communications equipment), 14.2 per cent (transportation equipment), 6 per cent (food), 7.2 per cent (general machinery), 7.2 per cent (stone, clay and glass) and 7.5 per cent (non-ferrous metals).
} 
As suggested in Griliches and Mairesse (1984), and undertaken by Goto and Suzuki (1989), we measure output (Q) by value added, deflated by the wholesale price index, rather than by sales. Another consideration is that one element of the observations on non-energy intermediate materials or energy input is unavailable. Labor $(\mathrm{L})$ is measured simply by the total number of employees because there is no available information on the labor working hours of firms. Note that R\&D manpower is deducted from labor since R\&D manpower is evaluated as R\&D expenditure. Our measure of physical capital (K) is total fixed gross assets; however, fixed gross assets in firms' financial statements are measured by nominal value (book value). We use the gross fixed capital price index from The Trends in Multi-factor Productivity, published by the Directorate-General of Budget, Accounting and Statistics, to deflate total fixed gross assets.

Not only is the composition of R\&D expenditure little known, but the available data concerning real $\mathrm{R} \& \mathrm{D}$ expenditure is also bedeviled by the lack of a suitable price index for R\&D inputs. In view of the inherent difficulties, most of the previous studies have adopted the same means used by US government officials, i.e., the use of the gross domestic product index to deflate R\&D expenditure. However, based on the GDP deflator, the rate of increase of $R \& D$ expenditure is usually overestimated. Here we construct the deflator index to deflate R\&D expenditure as in Mansfield et al. (1983). ${ }^{9}$

\section{THE RESULTS}

Since the analyzed sample is a panel data set, a random effects model is assumed in our analysis. ${ }^{10}$ A number of different models based upon equation (2) are estimated using

\footnotetext{
${ }^{9}$ Although we used the GDP deflator of each industry to deflate R\&D expenditure and then constructed R\&D capital, such an alternative construction makes little difference to the estimates.

${ }^{10}$ Equation (2) can be treated as a fixed or random effects panel model. Since the chi-square tests, suggested by Hausman (1978), come from different models based upon equation (2) show that the exploratory variables are most likely uncorrelated with the individual effects, a random effects panel model is assumed in this study.
} 
feasible generalized least squared method (FGLS). ${ }^{11}$ The estimates of the production function with and without year dummy variables (with year dummies as opposed to a time trend) are listed separately in Tables 2 and 3. Note that Tables 2 and 3 also provide the estimates of the product term of $\mathrm{R} \& \mathrm{D}$ capital by assets for all firms, as well as separately for high-tech and other firms. The estimates, denoted by $\gamma_{\mathrm{s}}$, of the product of R\&D stock by assets are used to test the Schumpeterian hypothesis.

Table 2 Production function estimates, excluding year dummies

\begin{tabular}{|c|c|c|c|c|c|c|}
\hline Regressions & $\alpha$ & $\gamma$ & $\lambda$ & $\gamma_{\mathrm{s}}^{\mathrm{a}}$ & $\mathrm{R}^{2}$ & MSE \\
\hline \multicolumn{7}{|l|}{ All firms $(\mathrm{N}=136)$} \\
\hline (1) & $\begin{array}{l}0.485^{b} \\
(0.071)\end{array}$ & $\begin{array}{l}0.187^{b} \\
(0.031)\end{array}$ & $\begin{array}{c}0.037^{\mathrm{c}} \\
(0.015)\end{array}$ & & 0.352 & 0.167 \\
\hline (2) & $\begin{array}{l}0.467^{b} \\
(0.079)\end{array}$ & $\begin{array}{l}0.184^{b} \\
(0.032)\end{array}$ & $\begin{array}{l}0.037^{\mathrm{c}} \\
(0.015)\end{array}$ & $\begin{array}{c}0.004 \\
(0.007)\end{array}$ & 0.354 & 0.168 \\
\hline \multicolumn{7}{|l|}{ High-tech firms $(\mathrm{N}=43)$} \\
\hline (3) & $\begin{array}{l}0.305^{b} \\
(0.115)\end{array}$ & $\begin{array}{l}0.297^{b} \\
(0.073)\end{array}$ & $\begin{array}{l}0.125^{b} \\
(0.032)\end{array}$ & & 0.468 & 0.190 \\
\hline (4) & $\begin{array}{c}0.325^{\mathrm{c}} \\
(0.130)\end{array}$ & $\begin{array}{c}0.299^{b} \\
(0.074)\end{array}$ & $\begin{array}{l}0.125^{6} \\
(0.033)\end{array}$ & $\begin{array}{l}-0.003 \\
(0.017)\end{array}$ & 0.468 & 0.191 \\
\hline \multicolumn{7}{|l|}{ Other firms $(\mathrm{N}=93)$} \\
\hline (5) & $\begin{array}{l}0.674^{b} \\
(0.087)\end{array}$ & $\begin{array}{c}0.055 \\
(0.037)\end{array}$ & $\begin{array}{c}0.021 \\
(0.016)\end{array}$ & & 0.326 & 0.133 \\
\hline (6) & $\begin{array}{l}0.613^{b} \\
(0.094)\end{array}$ & $\begin{array}{c}0.049 \\
(0.037)\end{array}$ & $\begin{array}{c}0.021 \\
(0.016)\end{array}$ & $\begin{array}{c}0.017^{\mathrm{d}} \\
(0.010)\end{array}$ & 0.333 & 0.133 \\
\hline
\end{tabular}

Notes:

${ }^{\text {a }}$ Figures in parentheses are estimated standard errors.

${ }^{\mathrm{b}}$ Significant at the 1 per cent level.

${ }^{\mathrm{c}}$ Significant at the 5 per cent level.

${ }^{\mathrm{d}}$ Significant at the 10 per cent level.

${ }^{11}$ Before estimating the model, in order to test the assumption of constant returns to scale with respect to the conventional factors, we rewrite the equation (2) as: $(q-k)_{\mathrm{I}}=\mathrm{a}+\lambda t+\alpha(l-k)_{i t}+\omega k_{i t}+\gamma_{i t}+v_{i t}$, where $\omega$ $=\alpha+\beta-1$. If $\omega$ is significantly different to zero, the constant returns to scale for labor and physical capital can then be rejected. Here the estimate of $\omega$ is approximately $0.021(\mathrm{t}=0.96, \mathrm{P}>0.05)$, which indicates that the assumption is not rejected at the 5 per cent significance level. 
Table 3 Production function estimates, including year dummies

\begin{tabular}{|c|c|c|c|c|c|}
\hline Regressions & $\alpha$ & $\gamma$ & $\gamma_{\mathrm{s}}{ }^{\mathrm{a}}$ & $\mathrm{R}^{2}$ & MSE \\
\hline \multicolumn{6}{|l|}{ All firms $(\mathrm{N}=136)$} \\
\hline$\left(1^{\prime}\right)$ & $\begin{array}{l}0.472^{\mathrm{b}} \\
(0.071)\end{array}$ & $\begin{array}{l}0.199^{\mathrm{b}} \\
(0.031)\end{array}$ & & 0.360 & 0.165 \\
\hline$\left(2^{\prime}\right)$ & $\begin{array}{l}0.459^{b} \\
(0.079)\end{array}$ & $\begin{array}{l}0.197^{b} \\
(0.032)\end{array}$ & $\begin{array}{c}0.003 \\
(0.007)\end{array}$ & 0.362 & 0.160 \\
\hline \multicolumn{6}{|l|}{ High-tech firms $(\mathrm{N}=43)$} \\
\hline$\left(3^{\prime}\right)$ & $\begin{array}{l}0.292^{b} \\
(0.117)\end{array}$ & $\begin{array}{l}0.308^{\mathrm{b}} \\
(0.074)\end{array}$ & & 0.473 & 0.191 \\
\hline$\left(4^{\prime}\right)$ & $\begin{array}{l}0.308^{c} \\
(0.132)\end{array}$ & $\begin{array}{l}0.309^{b} \\
(0.075)\end{array}$ & $\begin{array}{l}-0.003 \\
(0.011)\end{array}$ & 0.473 & 0.192 \\
\hline \multicolumn{6}{|l|}{ Other firms $(\mathrm{N}=93)$} \\
\hline$\left(5^{\prime}\right)$ & $\begin{array}{l}0.668^{\mathrm{b}} \\
(0.087)\end{array}$ & $\begin{array}{l}0.070^{\mathrm{d}} \\
(0.037)\end{array}$ & & 0.346 & 0.129 \\
\hline$\left(6^{\prime}\right)$ & $\begin{array}{l}0.613^{b} \\
(0.093)\end{array}$ & $\begin{array}{l}0.064^{d} \\
(0.037)\end{array}$ & $\begin{array}{c}0.016 \\
(0.010)\end{array}$ & 0.351 & 0.129 \\
\hline
\end{tabular}

Notes:

${ }^{a}$ Figures in parentheses are estimated standard errors.

${ }^{\mathrm{b}}$ Significant at the 1 per cent level.

${ }^{\mathrm{c}}$ Significant at the 5 per cent level.

${ }^{\mathrm{d}}$ Significant at the 10 per cent level.

The comparisons of Table 2 and Table 3 clearly show that using year dummy variables instead of a linear trend makes little difference to the estimates of the whole sample. The estimate of $R \& D$ capital elasticity $(\gamma)$, lying between 0.18 and 0.20 , is significant at the 1 per cent level, with the results showing that R\&D has a significant impact on productivity growth.

Since the sample comprised of firms engaging in $R \& D$ in rather diverse industries, it was also of interest to investigate the differences between sectors. When the sample is split into two categories, the estimates for the two groups are indeed rather distinct. ${ }^{12}$ The estimate of R\&D capital elasticity, at around 0.30 for high-tech firms, is much larger than for other firms. Note that the estimate of R\&D output elasticity for other firms is around only 0.06 , which is even insignificant in the model without year dummies. In addition, although the difference in the estimated time-trend coefficients (the rate of technical

\footnotetext{
12 Dividing the sample into two allows for much of the heterogeneity, bringing down the sum of the square of errors (SSE) by around 12 per cent (corresponding to a high $\mathrm{F}$ ratio of 16.05, $\mathrm{p}<0.01$ ).
} 
progress $\lambda$ ) between high-tech firms and other firms is rather significant, the estimates of $\lambda$ are significant in the high-tech firms $(\lambda=0.125, \mathrm{p}<0.01)$ but insignificant for other firms.

Given estimates of $\gamma$, the estimates of $d Q / d R$ are calculated by multiplying the estimates of $\gamma$ multiplied by the ratio of value added to the stock of R\&D. The estimated average rates of return on $R \& D$ investment for the whole sample during the periods 1996-2000 were around 23 to 25 per cent. Compared to the findings of previous studies that the analytical unit is at firm level - our results are consistent with the similar estimates of 21 per cent for the US (Lichtenberg and Siegel, 1991) and 27 per cent for the UK (Wakelin, 2001), but considerably lower than the 40 per cent found in Japan (Goto and Suzuki, 1989). Furthermore, the estimated rates of return on investment in R\&D for each industry, for the years 1996 to 2000, are listed in Table 4. The estimates in Table 4 suggest that the average rates of return on $R \& D$ capital for the high-tech industry, at around 35 per cent, are much larger than in other industries, at around 8 to 10 per cent.

Table 4 Average rates of return on $R \& D$ investment*

\begin{tabular}{|c|c|c|c|c|c|}
\hline & & & & & Unit: 0 \\
\hline Industry & 1996 & 1997 & 1998 & 1999 & 2000 \\
\hline Food & $\begin{array}{c}9.79 \\
(2.50)\end{array}$ & $\begin{array}{c}9.24 \\
(1.87)\end{array}$ & $\begin{array}{c}8.97 \\
(1.75)\end{array}$ & $\begin{array}{c}8.75 \\
(0.79)\end{array}$ & $\begin{array}{c}8.96 \\
(0.95)\end{array}$ \\
\hline Chemicals & $\begin{array}{c}8.54 \\
(1.36)\end{array}$ & $\begin{array}{c}8.17 \\
(1.38)\end{array}$ & $\begin{array}{l}7.96 \\
(1.93)\end{array}$ & $\begin{array}{c}7.59 \\
(1.02)\end{array}$ & $\begin{array}{l}7.84 \\
(0.89)\end{array}$ \\
\hline Textiles & $\begin{array}{c}9.60 \\
(2.37)\end{array}$ & $\begin{array}{c}9.30 \\
(2.28)\end{array}$ & $\begin{array}{c}8.94 \\
(1.11)\end{array}$ & $\begin{array}{c}8.28 \\
(1.03)\end{array}$ & $\begin{array}{c}8.75 \\
(0.95)\end{array}$ \\
\hline Machinery & $\begin{array}{c}8.32 \\
(2.12)\end{array}$ & $\begin{array}{c}8.12 \\
(1.98)\end{array}$ & $\begin{array}{l}8.08 \\
(1.16)\end{array}$ & $\begin{array}{c}7.93 \\
(1.06)\end{array}$ & $\begin{array}{c}8.03 \\
(1.14)\end{array}$ \\
\hline Metals & $\begin{array}{l}10.73 \\
(2.67)\end{array}$ & $\begin{array}{l}10.04 \\
(2.41)\end{array}$ & $\begin{array}{l}9.88 \\
(2.44)\end{array}$ & $\begin{array}{c}9.66 \\
(2.11)\end{array}$ & $\begin{array}{c}9.90 \\
(2.01)\end{array}$ \\
\hline $\begin{array}{l}\text { Electronic } \\
\text { equipment }\end{array}$ & $\begin{array}{l}36.84 \\
(4.97)\end{array}$ & $\begin{array}{l}35.97 \\
(4.47)\end{array}$ & $\begin{array}{l}35.31 \\
(4.23)\end{array}$ & $\begin{array}{l}34.99 \\
(4.11)\end{array}$ & $\begin{array}{l}35.12 \\
(3.91)\end{array}$ \\
\hline
\end{tabular}

Note: *Figures in parentheses are standard deviations.

The Schumpeterian hypothesis (1950) supported the belief of a greater likelihood of large firms both undertaking research activities, and achieving a measure of success. 
However, although Link (1981) found evidence of a systematic relationship between firm size and the impact of $R \& D$ on productivity, the empirical results of Lichtenberg and Siegel (1991) did not provide support for the Schumpeterian hypothesis. In our investigation, using total assets as a proxy for firm size, the estimates are positive for all firms, irrespective of whether or not the model contains year dummy variables, but insignificant at the 5 per cent level.

When the sample is divided into two categories (high-tech firms and other firms), the $\gamma_{\mathrm{s}}$ estimates (the parameter of the product term of R\&D capital by total assets) are still insignificant. Obviously, with respect to R\&D impact on productivity, we are unable to determine from these findings whether different size 'regimes' exist. Aside from total fixed assets, we also use sales as a proxy variable for firm size. At the 5 per cent significance level, the tests of the estimates of $\gamma_{\mathrm{s}}$ still do not demonstrate that the impact of R\&D on productivity growth is an increasing function of firm size. ${ }^{13}$

In addition, the estimates listed in Tables 2 and 3 also show that the labor share $(\alpha)$ in high-tech firms is small. One possible explanation is that the value added in high-tech firms is created mainly through their R\&D efforts, such as new product development, represented by the amount of $R \& D$ expenditure, and the input of $R \& D$ manpower is deducted from the total numbers of employees. Since the contribution from ordinary labor (the remaining employees of totality) to value added is always lower, the estimates here seem to be reasonable. The results are also consistent with the finding of 0.27 by Griliches and Mairesse (1984) in scientific firms ( $\mathrm{N}=77)$.

Based on the estimates of $\alpha$ for each of the two categories, and the conventional

13 One attribution of the statistical insignificance is that all of our sample firms are 'large' firms. However, firm size amongst these so-called large firms differs significantly. For example, in 2000, the average amount of total fixed assets in high-tech firms was NT\$15,187,200, and the standard deviation was NT\$8,760,197. The coefficient of variation (the ratio of standard deviation to mean) exceeds 50 per cent. 
definition of TFP $\left(\mathrm{TFP}=\mathrm{Q} / \mathrm{L}^{\alpha} \mathrm{K}^{1-\alpha}\right)$, we can further calculate the annual TFP growth rates for each industry. These estimated are listed in Table 5, which shows that there was a dramatic decline in TFP growth rates in 1998, which nevertheless started to rise again after 1999. ${ }^{14}$ The results show that the TFP growth in these industries seems to depend upon short-term fluctuations, and one obvious and possible explanation for this is the severe impact on the Taiwanese economy from the Asian financial crises between the fourth quarter of 1997 and the first quarter of 1999.

Table 5 Average annual rates of TFP growth*

\begin{tabular}{lccccc}
\hline \multicolumn{1}{c}{ Industry } & 1996 & 1997 & 1998 & 1999 & 2000 \\
\hline \multirow{2}{*}{ Food } & 5.14 & 0.54 & -16.01 & 7.67 & 5.73 \\
& $(2.23)$ & $(2.83)$ & $(5.82)$ & $(2.35)$ & $(2.78)$ \\
Chemicals & 2.31 & -0.15 & -19.63 & 12.50 & 5.46 \\
& $(2.72)$ & $(2.39)$ & $(3.76)$ & $(2.80)$ & $(1.72)$ \\
Textiles & 1.24 & 0.04 & -15.28 & -6.30 & 7.39 \\
& $(2.11)$ & $(2.41)$ & $(2.71)$ & $(2.88)$ & $(2.39)$ \\
Machinery & 4.12 & 0.95 & -15.82 & 5.40 & 8.33 \\
\multirow{2}{*}{ Metals } & $(2.97)$ & $(3.18)$ & $(5.92)$ & $(2.25)$ & $(2.97)$ \\
\multirow{2}{*}{ Electronic equipment } & 2.78 & 0.59 & -1.19 & -0.60 & -1.49 \\
& $(1.98)$ & $(1.74)$ & $(1.45)$ & $(1.52)$ & $(1.72)$ \\
& 6.39 & 9.08 & -7.26 & 4.41 & 13.21 \\
\end{tabular}

Note: * Figures in parentheses are standard deviations.

\section{CONCLUSIONS}

In this study, we have analyzed the relationship existing between output (value added), employment, physical capital and R\&D capital, based upon a complete sample of 136 large firms listed in the TSE over the period 1994-2000. Our findings suggest that R\&D investment was a significant determinant of firm productivity growth during the second half of the 1990s. For the whole sample, R\&D output elasticity was around 0.18 ; however, when the sample is divided into two categories, high-tech and other firms, we

\footnotetext{
${ }^{13}$ This trend is consistent with the calculation reported in The Trend in Multi-factor Productivity (DGBAS, 2001). However, the figures listed in Table 5 cannot be compared with overall estimates of total
} 
observe a statistically significant difference in R\&D elasticity between the two samples. The R\&D elasticity for high-tech firms is around 0.3 , but only 0.07 for other firms. In addition, we find that the average rate of return on investment in high-tech firms, at around 35 per cent, is larger than that estimated in other firms, at around 9 per cent. Our study also demonstrates that TFP growth declined across all the selected industries in 1998, but then started to pick up again after 1999. We speculate that the slump in TFP growth rates in 1998 can be attributed, to a large extent, to the Asian financial crisis. Moreover, our empirical results do not support the Schumpterian hypothesis, which states that the impact of R\&D on productivity is an increasing function of firm size.

Nevertheless, a couple of related points need to be discussed further. Firstly, the impact on productivity from these different types of R\&D may differ markedly. In general terms, R\&D work can be classified into three types, basic research, applied research and technical development. A number of studies have found that the contribution from basic research is greater than that of either applied research or technical development (see for example, Griliches and Siegel, 1991; Martin, 1998; Salter and Martin, 2001). However, since the proportion of R\&D expenditure spent on basic research in Taiwanese manufacturing firms has been rather small, our estimations should still be valid, even though we do not take into consideration the distinction between these different types of R\&D.

Secondly, the double counting of capital and R\&D capital may bias the estimated effects of R\&D. The estimate of $R \& D$ intensity or $R \& D$ capital is not particularly accurate when certain types of expenditure are accounted for in both R\&D capital and ordinary capital (Schankerman, 1981). R\&D expenditure in Taiwan has been clearly 
defined as all spending attributed to R\&D activities such as labor costs, administration, maintenance, and the acquisition of equipment for R\&D purpose (NSC, 2001). In accordance with the 'Statute for Industrial Upgrading', the R\&D expenditure of any firms in Taiwan applying for R\&D tax credits is closely scrutinized by the tax authorities, therefore, the purchase of equipment for $R \& D$ projects has to be recorded in $R \& D$ expenses, but not necessarily in fixed assets. Thus, potential double counting of capital should have little impact on the estimated effects of R\&D.

Thirdly, capital utilization rates should be considered in this analysis. ${ }^{15}$ In this study we have assumed that the short-term fluctuations in TFP came as a result of the Asian financial crisis. According to the findings of Wang et al. (1999), the Asian financial crisis damaged the exports of Taiwan's manufacturing industries and further reduced the utilization rates of manufacturing equipment. Thus, in order to exclude the demand shock from the Asian financial crisis, capital utilization rates should be regarded as an exploratory variable in the empirical model. Unfortunately, the capital utilization rates of the sample firms cannot be determined, and the variable cannot be constructed from other variables in the current data-set.

Fourthly, we have tried to separate the effects arising from inter-industry differences. Our analysis covers several industries, and in order to reduce the estimated bias of R\&D effects on the characteristic differences across these industries, we include industry dummies in the estimated model. However, the use of industry dummy variables brings down the sum of the square of errors (SSE) by only around 0.62 percent, corresponding to a low F ratio of $0.69(\mathrm{p}>0.05)$, and since the omnibus test (F-test) is not significant at

\footnotetext{
14 We appreciate the insightful suggestions provided by Professor Tsutomu Miyagawa and Jungho Yoo, and have tried to use industrial utilization rates of manufacturing equipment as a proxy for firms' capacity utilization rates. Although the estimates are not significant at the 5 per cent level, we consider that this insignificance is most likely the result of the use of a proxy.
} 
the 5 percent significant level, we ignore the impact of the industry dummy variable on the estimation.

Fifthly, one may doubt that the lager R\&D estimate in the high tech firms is coming spuriously at the expense of the labor coefficient. To address this concern, alpha is fixed to labor's share in the model. This restriction does not make the estimates significant difference compared to the findings in Tables 2 and 3. This robustness check confirms our finding that the R\&D output elasticity in high tech firms is significantly greater than that of other firms.

Finally, the sample period which we have observed, from 1994 to 2000, coincides with the IT boom; therefore, the potential exists for the IT bubble to have causes a disturbance to TFP growth trends during our study period. Throughout the IT bubble period, telecommunications and the Internet formed the backbone of IT investment, and although Taiwanese firms were involved in the IT boom, their Internet business was still at a rather embryonic stage and the telecommunications industry remained small, thus limiting the impact of the IT bubble.

Our study does of course have its limitations. First of all, as in the standard approach, we aggregate $R \& D$ expenditure linearly into $R \& D$ stock, ignoring the possibility that knowledge production depends non-linearly, not only on current efforts, but also on previously accumulated outcomes. Secondly, the results cannot explain the time-dimensional differences of R\&D performance across firms, since the time period is not yet long enough; our estimation also fails to reveal how the impacts of R\&D on productivity growth are actually realized. Thirdly, it may be worth trying to include in the estimation model a skills variable, such as the number of engineers and technicians; however, we cannot separate the effects of a skills variable because most of the firms in the sample omit many of the observations on these related variables. Fourthly, we do not 
discuss the more general topic of simultaneous R\&D decisions (simultaneity), which has recently entered into the discussion. If $R \& D$ is chosen on the basis of economic incentives, it is unlikely to be completely independent of the errors which affect the production relations that we attempt to estimate in this study. Finally, although our sample does cover 136 large manufacturing firms belonging to six industries, it clearly cannot represent all manufacturing firms; therefore, the interpretation of the findings in our study should remain conservative. 


\section{REFERENCES}

Barney, J.B. (1991), 'Firm resources and sustained competitive advantage', Journal of Management, 17: 99-120.

Baruch, Y. (1997), 'High technology organization: What it is, what it isn't', International Journal of Technology Management, 13(2): 179-195.

Begg, C.B. and J.A. Berlin (1988), 'Publication bias: A problem in interpreting medical data', Journal of the Royal Statistical Society, A, 151 (part3): 419-463.

Bound, J., Z. Griliches, B.H. Hall and A. Jaffe (1984), 'Who does R\&D and who patents?' in: Z. Griliches (ed.), R\&D, Patents and Productivity, 21-54. Chicago: University of Chicago Press.

Cuneo, P. and J. Mairesse (1984), 'Productivity and R\&D at Firm Level in French Manufacturing', in: Z. Griliches (ed.), R\&D, Patents and Productivity, 375-392. Chicago: University of Chicago Press.

DGBAS (2001), Trends in Multi-factor Productivity, Directorate-General of Budget, Accounting and Statistics, Executive Yuan, Taiwan.

Goto, A. and K. Suzuki (1989), 'R\&D capital rate of return on R\&D investment and spillover of R\&D in Japanese manufacturing industries', Review of Economics and Statistics, 71(4): 555-564.

Greene, W.H. (1991), Econometric Analysis, 2nd edn, NJ: Prentice-Hall, Inc.

Griliches, Z. (1979), 'Issues in assessing the contribution of research and development to productivity growth', Bell Journal of Economics, 10(1): 92-116.

Griliches, Z. (1980), 'R\&D and productivity slowdown', American Economic Review, 70(1): 343-348.

Griliches, Z. (1986), 'Productivity, R\&D and basic research at firm level in the 1970s', American Economic Review, 76(1): 141-154.

Griliches, Z. (1994), 'Explanations of productivity growth: Is the glass half empty?', American Economic Review, 84(1): 1-25.

Griliches, Z. (1995), 'R\&D and productivity', in: P. Stoneman (ed.), Handbook of the Economics of Innovation and Technological Change, Massachusetts: Cambridge Press, 52-89.

Griliches, Z. (1998), 'Patent statistics as economic indicators: A survey', in: Z. Griliches (ed.), R\&D, Patents and Productivity, Chicago: University of Chicago Press, 287-343.

Griliches, Z. and F. Lichtenberg (1984), 'R\&D and productivity growth at industry level: Is there still a relationship?', in: Z. Griliches (ed.), $R \& D$, Patents and Productivity, Chicago: University of Chicago Press, 465-501. 
Griliches, Z. and J. Mairesse (1984), 'Productivity and R\&D at firm level', in: Z. Griliches (ed.), R\&D, Patents and Productivity, Chicago: University of Chicago Press, 339-375.

Griliches, Z. and J. Mairesse (1998), 'R\&D and productivity growth: Comparing Japanese and US manufacturing firms', in: Z. Griliches (ed.), $R \& D$ and Productivity, Chicago: University of Chicago Press, 187-210.

Hall, B.H. and J. Mairesse (1995), 'Exploring the relationship between R\&D and productivity in French manufacturing firms', Journal of Econometrics, 65: 263-293.

Hanel, P. (2000), 'R\&D, inter-industry and international technology spillovers and the total factor productivity growth of manufacturing industries in Canada, 1974-1989', Economic Systems Research, 12(3): 345-361.

Hausman, J. A. (1978), 'Specification tests in econometrics', Econometrics, 46: 1251-1271.

Lichtenberg, F. and D. Siegel (1991), 'The impact of R\&D investment on productivity: New evidence using linked R\&D-LRD data’, Economic Inquiry, 29(2): 203-229.

Lin, H-L. and X.F. Lee (1996), 'The study of the relationship between patents and R\&D expenditures in Taiwan: An Application of non-negative integer model', Economics Articles, 24(2): 273-302 (in Chinese).

Link, A.N. (1981), Research and development activity in US manufacturing, NY: Proger.

Mansfield, E. (1965), 'Rates of return from industrial R\&D', American Economic Review, 55(3): 863-873.

Mansfield, E. (1969), 'Industrial research and development: Characteristics, costs and diffusion of results', American Economic Review, 59(1): 65-71.

Mansfield, E. (1980), 'Basic research and productivity increase in manufacturing', American Economic Review, 70(3): 863-873.

Mansfield, E., A. Romeo and L. Switzer (1983), 'R\&D price indexes and real R\&D expenditures', Research Policy, 12: 105-112.

Martin, F. (1998), 'The economic impact of Canadian university R\&D', Research Policy, 27: 677-687.

National Science Council (2001), Indicators of Science and Technology, National Science Council, Executive Yuan, Taiwan.

Odagiri, H. and S.Y. Kinukawa (1997), 'Contributions of channels of inter-industry R\&D spillovers: An estimation of Japanese high-tech industries', Economic Systems Research, 9(1): 127-142.

Parkes, A. and Z. Griliches (1984), 'Patents and R\&D at firm level: A first look', in: Z. Griliches (ed.), R\&D, Patents and Productivity, Chicago: University of Chicago Press, $55-72$. 
Parkes, A. and M. Schankerman (1984), 'The rate of obsolescence of patents, research gestation lags and the private rates of return to research and resources', in: Z. Griliches (ed.), $R \& D$, Patents and Productivity, Chicago: University of Chicago Press, 73-88.

Peteraf, M.A. (1993), 'The cornerstones of competitive advantage: A resource-based view', Strategic Management Journal, 14: 179-191.

Rosenthal, R. (1979), 'The 'file drawer' problem and tolerance for null results', Psychological Bulletin, 86: 638-641.

Salter, A.J. and B.R. Martin (2001), 'The economic benefits of publicly-funded basic research: A critical review', Research Policy, 30: 509-532.

Schankerman, M. (1981), 'The effects of double counting and expensing on the measured returns to R\&D', Review of Economics and Statistics, 63(3): 454-458.

Scherer, F.M. (1983), 'R\&D and declining productivity growth', American Economic Review, 73(1): 215-218.

Scherer, F.M. (1993), 'Lagging productivity growth: Measurement technology and shock effect', Empirica, 20: 5-24.

Schumpeter, J.A. (1950), Capitalism, socialism and democracy, 3rd. edn. NY: Harper \& Row.

Tsai, K-H. (1997), 'The impact of R\&D on patents in Taiwan', Sun Yat Sen Management Review, 5(2): 25-46 (in Chinese).

Van Meij, H. (1997), 'Measuring inter-sectoral spillovers: French Evidence', Economic Systems Research, 9(1): 25-46.

Vouri, S. (1997), 'Inter-industry technology flows and productivity in Finnish manufacturing', Economic Systems Research, 9(1): 67-80.

Wakelin, K. (2001), 'Productivity growth and R\&D expenditure in UK manufacturing firms', Research Policy, 30: 1079-1090.

Wang, J.C., P-H Hsin and K-H Tsai (1999), The impact of Asian financial crisis on Taiwan's industrial competitiveness. Taipei: Chung-Hua Institution for Economic Research (in Chinese).

Wernefelt, B. (1984), 'A resource-based view of the firm', Strategic Management Journal, 5: 171-180.

Xu, T-D., J-C. Wang and K.H. Tsai (1998), The impact of technology expenditures on economic development, NSC Report (in Chinese). 